\title{
A cidade como sentimento: história e memória de um acontecimento na sociedade contemporânea - 0 incêndio do Gran Circus Norte-Americano em Niterói, $1961^{1}$
}

Paulo Knauss

UFF

\section{RESUMO}

O estudo relaciona história do acontecimento e história urbana para discutir a problemática da memória nas sociedades contemporâneas. A pesquisa aborda o caso do incêndio do Gran Circus Norte-Americano, ocorrido em 17 de dezembro de 1961, na cidade de Niterói, então capital do antigo estado do Rio de Janeiro. $\mathrm{O}$ fato é conhecido como um dos maiores incêndios da história em termos de número de vítimas fatais, e se afirmou na memória da cidade. O trabalho tem como base fontes da imprensa e fontes orais. A análise demonstra como o acontecimento se estabelece entre história e memória e define a cidade como sentimento.

Palavras-chave: Gran Circus Norte-Americano; incêndio; Niterói.

\section{ABSTRACT}

The study connects urban history and event history to discuss the memory in contemporary societies. The research analyzes the fire of the Gran Circus Norte-Americano in December 17, 1961, in the city of Niterói, when it still was the capital of the state of Rio de Janeiro. The fact is known as one of the biggest fires in history in terms of fatal victims' number, and that has been established in the city memory. The work is based on press sources and oral sources. The analysis shows how the event is established between history and memory, and defines the city as feeling.

Keywords: Gran Circus Norte-Americano; fire; Niterói.

Toda cidade tem muitas histórias. Nem sempre a historiografia sobre as cidades reconhece essa multiplicidade e procura submeter a compreensão da história urbana a variáveis gerais e constantes que costuram a cidade e a representam como unidade de elementos complementares, num tempo linear. Nessa abordagem os acontecimentos da vida urbana não têm lugar e são trans- 
feridos para o plano da crônica da cidade. A historiografia sobre a cidade acompanha assim uma tendência geral da historiografia do século XX, especialmente a que se consagrou em plano internacional a partir da década de 1950 ao afirmar uma abordagem que valoriza acima de tudo uma interpretação estrutural e de caráter abrangente da história, em contraposição a uma historiografia cronológica de base factual. Instalou-se, portanto, um contexto historiográfico de negação do acontecimento. ${ }^{2}$

Pierre Nora levantou essa discussão historiográfica em um artigo originalmente publicado em 1972 e que se tornou referência importante para uma revisão da história do acontecimento. Sua publicação concomitante a um livro do famoso medievalista francês Georges Duby deu repercussão ao debate. ${ }^{3}$ Sob essa inspiração, este trabalho apresenta um estudo sobre o incêndio do circo ocorrido na cidade de Niterói, no antigo estado do Rio de Janeiro, no final do ano de 1961. Tal como propõe Pierre Nora, trata-se de analisar a produção do acontecimento em relação ao processo de metamorfose do acontecimento. Busca-se caracterizar representações do acontecimento para ir ao encontro do que Georges Duby definiu como "ressonâncias do acontecimento" (1993, p.11). Para tanto, a reflexão problematiza as relações entre história e memória, confrontando leituras de fontes de época com fontes orais. Desse modo, a história da cidade torna-se aqui um pretexto para discutir uma experiência urbana contemporânea do acontecimento.

\section{IMAGEM DA TRAGÉDIA}

Em 17 de dezembro de 1961 ocorreu um acontecimento inusitado na cidade de Niterói: o maior incêndio de circo de todos os tempos.

Imediatamente, a imprensa diária anunciava o número oficial de 238 mortos, mas já indicava um total de 260 vítimas fatais. ${ }^{4}$ Dois dias depois, anunciavam-se mais de 300 mortos, e, semanas depois, o número chegava a $400 .{ }^{5}$ Certo é que, entre a maioria das vítimas, famílias e, principalmente, crianças chamavam atenção. Incluem-se, ainda, muitos adultos entre as vítimas, pois, dada a falta de opções de entretenimento na cidade, muitos foram assistir à atração social do momento na cidade. Mas, além disso, é preciso contabilizar inúmeros sobreviventes marcados pela perda de familiares próximos, e sua luta para sobreviver e enfrentar as seqüelas físicas e psíquicas da experiência direta com o fogo.

Num primeiro movimento, a imprensa terminou definindo o aconteci- 
mento como tragédia. A revista ilustrada Manchete apresentou em suas páginas esta descrição:

Foi de fato a maior tragédia ocorrida até hoje no Brasil; não só num circo, mas em qualquer local de diversão pública. Como tochas vivas corriam crianças e adultos, atropelando-se uns aos outros, na tentativa desesperada de alcançar a estreita passagem por onde devia escoar-se toda a enorme multidão. Muitas pessoas caíram e foram pisoteadas, fazendo os esmagamentos quase tantas vítimas quanto as queimaduras. ${ }^{6}$

A Tribuna da Imprensa noticiou, ainda, que o circo se exibia em Niterói, em terreno na avenida Feliciano Sodré, desde a sexta-feira anterior, e que a sessão tomada pelo fogo era a segunda matinée do fim-de-semana e estava com lotação completa de 2.500 espectadores, naquela tarde. ${ }^{7} \mathrm{O}$ fogo se iniciou às $15 \mathrm{~h} 45$, no momento da apresentação dos trapezistas e que marcava o final do espetáculo, exatamente no instante de um dos pontos altos do programa: o salto tríplice. Em poucos minutos o incêndio destruiu o circo, segundo o jornal. ${ }^{8} \mathrm{O}$ depoimento publicado da trapezista informava que o fogo havia começado na arquibancada, ao lado esquerdo do túnel de saída. ${ }^{9}$

A revista $O$ Cruzeiro descreveu assim a situação do incêndio:

E a confusão tomou conta do "Gran Circo Norte-Americano". Num instante, milhares de pessoas, homens, mulheres e crianças, aos trambolhões, tentaram ganhar a porta de saída. O aviso chegara tarde. A lona tomada pelo fogo, ardia em toda a extensão. E, pouco depois, desabava sobre a multidão. Gritos lancinantes ouviam-se por toda parte. Depois, o silêncio e a morte envolta numa montanha de cinzas. ${ }^{10}$

O jornal Tribuna da Imprensa completava a descrição dos fatos com estas palavras:

Em menos de 20 minutos o circo ficou completamente destruído, com um montão de corpos carbonizados na porta principal e outros espalhados pelas cadeiras e debaixo das arquibancadas. Um pouco longe do circo, era este o espetáculo: uns se arrastando quase em frente à estação [de trem] da Leopoldina, outros rasgando suas roupas (em chamas) aos gritos. Os que conseguiram sair sem ferimento gritavam por socorro. Dois minutos depois, chegava o Corpo de Bombeiros, que teve só um trabalho: juntar os mortos aos caminhões dos particulares e mandá-los para o Necrotério. Praticamente não havia mais fogo. ${ }^{11}$ 
O diário informava, ainda, que aquele contexto inusitado havia sido marcado pela reação de um elefante que estava pronto para ser levado à cena. Assustado pelas chamas, o animal correu, arrastando parte da lona, salvando assim grande número de espectadores. ${ }^{12}$

O socorro foi quase imediato, considerando que o quartel dos bombeiros era muito próximo, segundo a imprensa. Com a ajuda de populares que estavam no local, os bombeiros, assim que chegaram, começaram a enrolar com cobertores os corpos em chamas. Todos tentaram retirar vítimas dos escombros. Antes mesmo de chegarem as ambulâncias, carros particulares conduziam os feridos para o atendimento médico. Nesse meio tempo, alguns que escaparam ilesos buscavam familiares. ${ }^{13}$

A descrição de O Cruzeiro resume a cena:

Centenas de sapatos de homens, mulheres e crianças espalhados pelo picadeiro, atestavam toda a dramaticidade da tragédia que atingira o Circo Norte-Americano. No meio deles, uma mamadeira que não era mais usada pelo seu dono. A maior parte das vítimas era constituída de menores que tinha ido em busca de alegria e diversão. $\mathrm{O}$ futuro, porém, lhes reserva um cruel destino: a morte. ${ }^{14}$

Na seqüência dos fatos, a cidade foi intensamente mobilizada pelo processo de reconhecimento e dos corpos, que durou alguns dias e que foi realizado no estádio esportivo Caio Martins. Os corpos carbonizados foram enfileirados em ala coberta do edifício para o seu reconhecimento pelos que buscavam seus parentes. No Caio Martins, os corpos ficavam cobertos com panos brancos doados pelo povo. Ali mesmo, uma vez reconhecidos, eram colocados nos caixões para o sepultamento. ${ }^{15} \mathrm{O}$ campo de futebol central do estádio foi transformado no que Fatos \& Fotos caracterizou como "a maior e mais triste carpintaria do mundo”, exibindo imagens nas suas páginas ilustradas. As páginas da revista ilustrada exploraram as imagens do cenário preparado pela necessidade de disponibilizar grande número de caixões de diferentes tamanhos de uma só vez. ${ }^{16}$ Informava-se que o governador havia convocado todos os marceneiros e carpinteiros de Niterói para a fabricação dos esquifes em regime de urgência. Muitos acorreram voluntariamente. Assim, dizia-se que em apenas 24 horas teriam ficado prontos caixões de todos os tamanhos em quantidade suficiente. Chamava atenção, no entanto, o número de caixões para crianças. "Círculos dantescos de desesperos e de pranto", definiu O Cruzeiro. ${ }^{17} \mathrm{~A}$ imprensa ilustrada caracterizou a imagem do luto da cidade. 
Nas páginas de reportagem, o resultado imediato dos fatos indicado foi o povoamento do cotidiano da cidade, durante vários dias, com velórios e enterros. A Tribuna da Imprensa anunciou que a cidade de Niterói teria assistido em silêncio à passagem de 143 caixões que foram sepultados no cemitério do Maruí. ${ }^{18}$ Operários da prefeitura foram convocados pra ampliar o número de covas. O trabalho era realizado ao mesmo tempo em que se realizavam vários funerais concomitantes no cemitério. ${ }^{19}$ Mario de Moraes, nas páginas da revista $O$ Cruzeiro, descreveu assim o quadro da cidade: "O comércio e a indústria, portas semi-cerradas, testemunhavam o pesar dos fluminenses pelo drama que se abatera sobre sua cidade. Os carros passavam, fitas pretas presas nas carroçarias. Havia desolação em toda parte...”. ${ }^{20}$ Não escapou da imprensa, ainda, o retrato de algumas reações individuais de desespero. Assim, deu-se a notícia de que um senhor, dono de botequim, destruiu seu estabelecimento comercial ao enlouquecer diante do fato da perda da mulher e dos filhos. Outros casos apareceram nos jornais, como por exemplo, do homem que enlouqueceu acusando a vizinha por ter levado seus filhos ao circo, ou da senhora que insistia em procurar o filho desaparecido. ${ }^{21}$

Ao acompanhar as páginas da imprensa, verifica-se uma representação do acontecimento em que o programa de domingo familiar de lazer, que deveria ser marcado pelo encontro de gerações em torno da festa, terminou por inscrever a dor na cidade, associando o acontecimento à tragédia. A representação está assim baseada na exploração de dicotomias entre alegria e tristeza, crianças e adultos, vida e morte - e o fogo aparece como fato e símbolo do acontecimento. Essa representação mobiliza, ainda hoje, imagens que provocam sentimentos.

Isso se sustenta num forte tom de crônica que caracteriza o tratamento da imprensa à descrição dos fatos. Dado o imprevisto e a instantaneidade do acidente, dificilmente os repórteres teriam tido chance de participar das cenas ocorridas com tanta proximidade. As fotos da imprensa ilustrada deixam isso claro, pois só há fotos dos escombros vazios ou de cenas dos desdobramentos. 


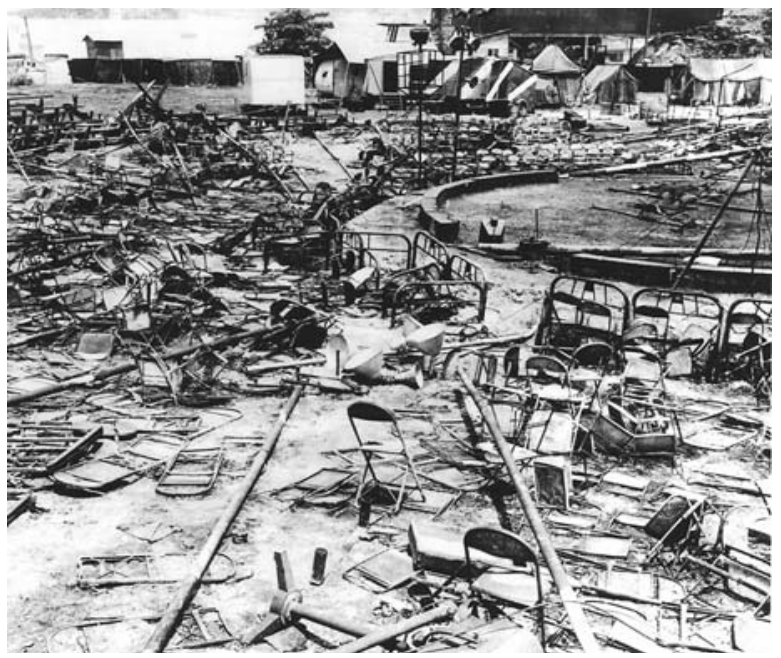

Foto 1 - Picadeiro vazio. Fonte: Correio da Manhã. Arquivo Nacional.

Certamente, a reportagem apropriou-se de informações de testemunhas do local. Mas, ao não mencioná-las, o tom da crônica de olhar pessoal se impõe à descrição jornalisticamente conduzida. Acrescente-se, ainda, que a atenção a detalhes como os sapatos e a mamadeira perdidos no picadeiro destruído, o recurso a imagens como de "tochas vivas" ou de "pessoas se arrastando" e "rasgando roupas aos gritos" para caracterizar o desespero das vítimas, bem como a observação dos carros com fitas para registrar o luto metaforizam os fatos. Desse modo, pode-se dizer que o tom pessoal e a metaforização dos fatos afirmam a empatia como princípio do tratamento dado pela imprensa da época. A empatia caracteriza justamente a vontade de transpor a distância entre os fatos e o observador como princípio analítico, permitindo que o discurso do observador se iguale ao da testemunha do acontecimento. Mas, nesse caso, a empatia serve também para aproximar o leitor e o autor do texto num mesmo plano de identidade, como se um falasse pelo outro. Ocorre, então, uma naturalização da percepção dos fatos a partir da mobilização de elementos e recursos que conferem uma imagem sensível e um significado íntimo ao sucedido, permitindo que leitores dos jornais e revistas fossem transportados para dentro da cena do acontecimento. Com isso, o retrato de dores individuais e localizadas na cidade se afirma como uma dor de todos os leitores e transpõe a experiência particular em experiência coletiva. A 
empatia como princípio permite, então, a construção da dor coletiva e estabelece um laço social com base no sentimento compartilhado.

\section{IMAGEM DA SOLIDARIEDADE}

Depois de apresentar o sentido trágico do episódio, a imprensa demarcou a presença da solidariedade. Um tratamento do acontecimento é desenvolvido ao enfatizar a mobilização social que envolveu o apoio às vítimas do incêndio de Niterói.

Assim, a imprensa noticiou que as vítimas do incêndio foram levadas para o hospital Antonio Pedro, Hospital dos Marítimos, Casa de Saúde São José, Hospital Santa Cruz e Hospital Luís Palmier, de áreas da região metropolitana do Rio de Janeiro. ${ }^{22}$ Em Niterói mesmo, o principal centro foi o Hospital Antonio Pedro, que acabou centralizando grande parte do atendimento às vítimas. A imprensa expôs o fato da carência de infra-estrutura hospitalar da cidade de Niterói e chamou atenção para a precariedade das condições para o socorro às vítimas e de fiscalização da prevenção e combate ao fogo. Principal hospital da cidade, o Antonio Pedro estava fechado havia cerca de 20 dias em razão de uma greve de acadêmicos, que defendiam a federalização do estabelecimento hospitalar diante das condições do serviço oferecidas pela prefeitura e pela falta de um hospital geral público importante na região da cidade. A carência da instituição era total, o que mobilizou intensamente a solidariedade que acorreu para fornecer o material necessário para o atendimento às vítimas. $\mathrm{O}$ empenho de órgãos públicos e particulares, assim como grande número de doadores de sangue voluntários garantiram o atendimento hospitalar. Medicamentos, roupas, camas, comida, tudo o que era necessário foi sendo recolhido ao hospital. ${ }^{23}$ Encontra-se ainda a informação de que o comércio e a indústria de Niterói ficaram de portas abertas pela noite adentro para garantir fornecimento de medicamentos e materiais, como também para atender feridos e realizar sepultamentos. Até a diretoria do Clube de Regatas Flamengo, mais conhecido pelo futebol, teria anunciado que colocava sua equipe à disposição de autoridades para organizar um jogo em benefício das vítimas. ${ }^{24} \mathrm{~A}$ imprensa informou, ainda, que senhoras da sociedade fluminense criaram fundo de assistência às vítimas do sinistro. ${ }^{25}$ Além disso, anunciou-se que as doações de cereais, frutas e carnes foram tão numerosas que abarrotaram o hospital, indo além do necessário. ${ }^{26}$ No Rio, o Hospital Silves- 
tre teria ainda colocado leitos à disposição do hospital Antonio Pedro. A União Fluminense de Estudantes decretou luto. ${ }^{27} \mathrm{O}$ envolvimento direto ou indireto da sociedade local, portanto, foi amplo e irrestrito, uma vez que toda a cidade (e a região metropolitana em que se insere Niterói) terminou envolvida no movimento de mobilização em torno das conseqüências do incêndio.

O convívio com a tragédia foi noticiado pela imprensa e obteve grande repercussão, o que promoveu o sentimento de solidariedade por toda parte do país e gerou ações de colaboração internacional para salvar os sobreviventes do fogo marcados por queimaduras em diferentes partes do corpo. De todo o país chegavam mensagens, como a do governador de São Paulo, Carvalho Pinto, e do prefeito de São Paulo, para manifestar sua solidariedade. ${ }^{28} \mathrm{Na}$ seqüência das notícias, a imprensa informou que vários países enviaram suas condolências ao governo brasileiro pelo grande número de vítimas. O presidente da Argentina, dr. Mario Muido, teria enviado telegrama ao presidente e ao primeiro-ministro, por exemplo, assim como a embaixada do Vaticano e outras representações diplomáticas. ${ }^{29} \mathrm{O}$ papa se manifestou, ainda, rezando missa pelos mortos do incidente. As diversas instâncias de governo se mobilizaram. O presidente da República, João Goulart enviou mensagem ao governador do estado e, em companhia do primeiro-ministro, Tancredo Neves, visitou o hospital para solidarizarem-se com as vítimas e a cidade. Créditos especiais foram concedidos pelo governo federal para o hospital Antonio Pedro. ${ }^{30} \mathrm{O}$ governo da Argentina, além de manifestar oficialmente o pesar pela tragédia, enviou uma equipe de seis médicos cirurgiões plásticos e oito enfermeiras, do Instituto Nacional de Queimados. ${ }^{31} \mathrm{O}$ auxílio médico completouse, ainda, com uma tonelada de medicamentos, plasma, soro, ataduras e gazes, segundo o noticiário de época. ${ }^{32}$ Noticiou-se, ainda, que a embaixada dos Estados Unidos entregara um estoque de antibióticos, ataduras e soros. ${ }^{33} \mathrm{Em}$ colaboração com a Cruz Vermelha, os Estados Unidos enviariam ainda nos dias seguintes mais de 500 frascos de plasma sangüíneo. ${ }^{34} \mathrm{O}$ governo do estado da Guanabara, a partir da cidade do Rio de Janeiro, colocou à disposição recursos médicos, assim como a prefeitura de São Paulo. No Rio de Janeiro, grande número de voluntários acorreu ao Banco de Sangue para fazer doação de sangue..$^{35} \mathrm{O}$ Correio da Manhã noticiou que mais de 700 pessoas foram ao Instituto de Hematologia. A Legião Brasileira de Assistência (LBA) assumiu o controle dos donativos às vítimas. ${ }^{36} \mathrm{~A}$ Força Aérea e o Exército apoiaram também o atendimento às vítimas hospitalizadas, segundo a imprensa, $\mathrm{e}$ a Rede Ferroviária Federal colocou caminhões à disposição dos trabalhos de 
assistência. ${ }^{37} \mathrm{O}$ jornal informou também que Celso Peçanha, governador do estado do Rio de Janeiro, determinou que presos de bom comportamento fossem trabalhar na abertura de sepulturas no cemitério de Maruí..$^{38}$ A primeiradama também se envolveu no trabalho de assistência às vítimas, segundo noticiou O Fluminense ${ }^{39}$ Além disso, consta que o governador estadual distribuiu nota oficial, anunciando que assumira pessoalmente a direção dos socorros, e decretou luto oficial por três dias, estado de calamidade pública e proibição de venda de bebidas alcoólicas no município de Niterói e na vizinha São Gonçalo, com o argumento de facilitar o trabalho da polícia. Segundo o Jornal do Brasil, durante a visita às vítimas hospitalizadas, o presidente João Goulart teria dito: "Vi o espetáculo mais triste de minha vida". ${ }^{40}$

Se o ocorrido tinha local e hora muito precisos nas páginas de revistas e jornais, a reação de ajuda parecia não ter fronteiras, pois a representação da imprensa apresentava uma mobilização que extrapolava o caráter local do acontecimento. Os sujeitos que emergem dos fatos são sujeitos sociais que representam estruturas gerais da sociedade como a Ciência (os médicos), a Igreja (o papa) e o Estado (o governador, o primeiro-ministro e o presidente da República), e que não identificam o contexto local. As doações e contribuições pareciam vir de todos os lados do mundo, fazendo de Niterói uma preocupação geral. Assim, diante do incêndio e de suas conseqüências, ainda que o acontecimento tenha sido local, a comoção pública era apresentada como vinda de todas as partes e, portanto, sem lugar preciso.

Nesse caso, encontra-se na imprensa uma descrição de reportagem que procura se caracterizar como olhar distanciado, fazendo pouco uso de metáforas. É por isso que se observa também a citação de depoimentos de personagens identificados pela matéria e que registram testemunhos efetivos. Assim, ainda que a escrita não apresente um tom íntimo, a solidariedade como tema confere, igualmente, uma dimensão sentimental ao acontecimento. Mas o sentimento de solidariedade é afirmado como valor universal. 


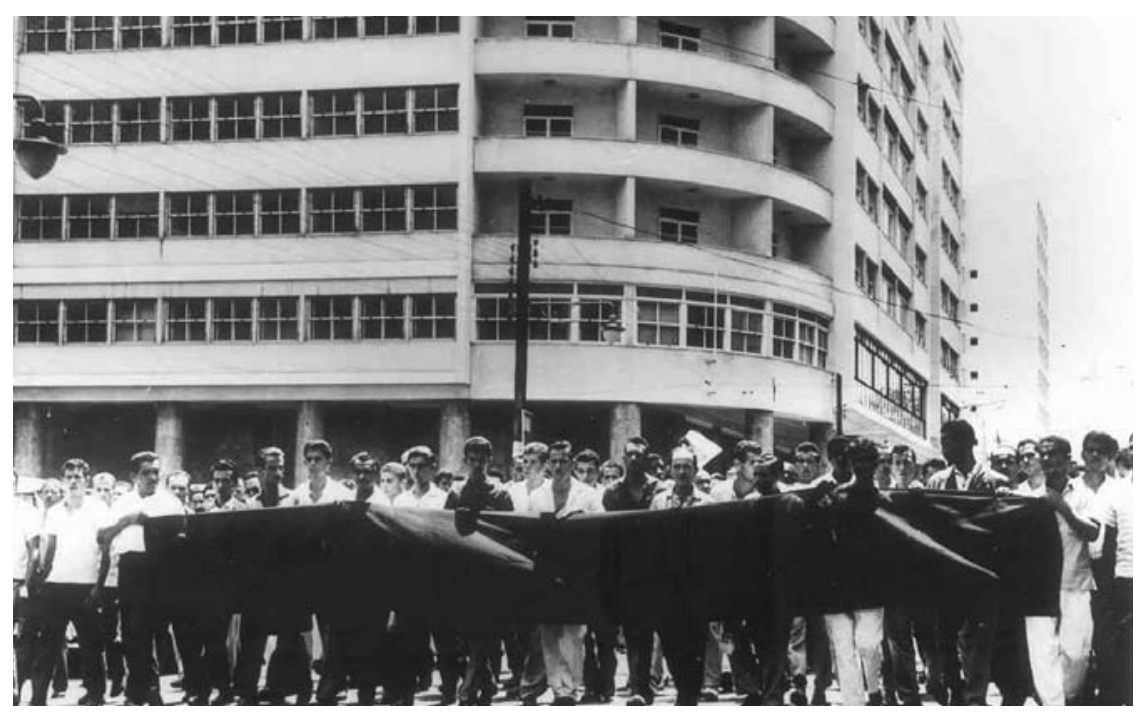

Foto 2 - Luto da cidade.

Fonte: Correio da Manhã. Arquivo Nacional.

\section{IMAGEM DO CRIME}

Dois dias após o incêndio, a imprensa noticiou a instalação de um inquérito policial sobre o sinistro. Segundo consta, o primeiro delegado indicado foi Roberto Brito de Menezes, que anunciou o início da tomada de depoimentos e a necessidade de conclusão do laudo pericial. ${ }^{41}$ Mas o proprietário do circo, sr. Stevanovich, apareceu no jornal Tribuna da Imprensa declarando: "Só mesmo um crime pode justificar o incêndio", e levantou a hipótese de que favelados expulsos da primeira sessão poderiam ter provocado o desastre. ${ }^{42}$ Depois dessa primeira declaração, o empresário só apareceria dias depois noutro jornal, anunciando em Porto Alegre, no Rio Grande do Sul, a decisão de não reconstituir o Gran Circus Norte-Americano. ${ }^{43} \mathrm{Na}$ sentença final do processo não consta seu depoimento à polícia.

Um dia depois, os jornais estamparam que "o circo não tinha condições para funcionar”, apoiados em declaração preliminar de perito. A partir daí, ficou apontada, nas páginas da imprensa, a precariedade das instalações elétricas, ausência de extintores de incêndio, presença de capim seco nas áreas do circo e falta de saída para a audiência, além de se mencionar a questão da 
negligência da autoridade que havia autorizado o funcionamento do circo. Além disso, os técnicos da perícia teriam informado à imprensa que a propagação do fogo foi facilitada pela parafina inflamável na cobertura de lona (e não de nylon, como se chegou a difundir), recentemente adquirida em São Paulo. ${ }^{44} \mathrm{O}$ comandante do Corpo de Bombeiros apareceu mais tarde em reportagens de modo a esclarecer que a vistoria considerou boas as condições de segurança da casa de espetáculo, o que havia sido confirmado por visita posterior do comandante Silvio Ribeiro, citado na matéria. ${ }^{45}$ Também o Diretor do Serviço de Censura do Estado do Rio apareceu, em reportagem, declarando que sua repartição fizera vistoria aprovando as condições de funcionamento do circo. ${ }^{46}$

Ao mesmo tempo, aparecia na imprensa a nota de que a polícia buscava alguns suspeitos. ${ }^{47}$ Os dois primeiros eram empregados da família Stevanovich, que tinham ameaçado em outra ocasião incendiar o circo Big Top. ${ }^{48} \mathrm{~A}$ caça ao terceiro suspeito demorou, mas, por fim, foi sobre este que recaíram as suspeitas mais fortes. ${ }^{49}$ Tratava-se de Adilson Marcelino Alves, conhecido como Dequinha, acusado por um empregado do circo de nome Maciel Felizardo, chamado também de Sujinho. Aparece, então, nos jornais a afirmação de que Dequinha era um ex-empregado que, depois de ser repreendido várias vezes em serviço pelo patrão, fora demitido, quando prometeu "botar fogo no circo". Além disso, no dia do incêndio, o denunciante teria visto Dequinha no local do incêndio, até que este desapareceu no momento em que as chamas surgiram..$^{50}$

Na mesma edição aparecia a foto e mais adiante a notícia de que a Secretaria de Segurança estadual comunicava oficialmente que o acusado, depois de ser preso no dia anterior e recolhido a uma unidade militar em Niterói, confessara o crime. Nesse primeiro depoimento, a imprensa indicava como motivo o desejo de vingança ${ }^{51}$ Havia uma nota que chama a atenção: "A confissão, segundo o secretário de Segurança Gouveia de Abreu, foi feita sem coação e assistida por um promotor", garantindo assim a integridade do processo. Depois, Dequinha teria sido levado ao local — com cuidados para protegê-lo de linchamento - para participar de reconstituição do ato e esclarecer detalhes. Em sua confissão, disse ter contado com a ajuda de Walter Rosa dos Santos, que atirou gasolina numa parte da lona antes de ele atear fogo. Walter e sua "amante" [ sic] Regina Maria da Conceição foram detidos..$^{52} \mathrm{Na}$ ocasião, nas páginas dos jornais se informava que Walter Rosa negava sua participação. E, na seqüência, consta que os acusados foram primeiro recolhidos à fortaleza de Santa Cruz, com o objetivo de resguardá-los da "fúria popular", fican- 
do, assim, sob custódia do exército para só num segundo momento serem transferidos para o Primeiro Batalhão da Polícia Militar. O motivo da transferência teria sido a recusa do exército em permitir a presença de jornalistas. ${ }^{53}$

Mas a apresentação dos acusados à imprensa, envolvida em um processo de ritualização oficial, terminou ganhando destaque nas páginas dos jornais. Na sede da Polícia Central, o próprio chefe de Gabinete Civil do governo estadual conduziu o ritual inusitado. Ele chamou atenção, inicialmente, de todos os presentes para a responsabilidade do momento diante da curiosidade pública, anunciando a interdição de armas, e insistindo na discrição. No entanto, organizou-se um cortejo com radiopatrulha à frente, com sirene ligada, para organizar a ida até o quartel onde estavam os presos. Segundo consta, o cortejo ficou dando voltas na cidade para despistar. No quartel, o próprio governador apresentou os criminosos e iniciou um interrogatório aberto. ${ }^{54}$ Adilson, o Dequinha, confirmou ter sido ele mesmo quem ateou o fogo, jogando um fósforo aceso na cobertura do circo. Explicou que fizera tudo porque brigara com o porteiro do circo. Admitia não ter medido as conseqüências, e que não imaginava que tantos morreriam. O governador chegou a perguntar se havia sofrido alguma violência, e o acusado respondeu levantando a camisa e mostrando partes do corpo. Ele ainda chorou e desmaiou. Dequinha voltou a repetir a história da participação de Walter Rosa — também chamado Bigode, que, por sua vez, insistiu em que não estava no circo na ocasião e apresentou seu álibi. O governador, no entanto, dizia que sua mulher o acusava, enquanto o marido desqualificava-a como "beberrona" e por isso não sabia o que dizia. Além disso, Walter se recusava a admitir que tivesse comprado gasolina, como lhe imputavam, mesmo o governador afirmando ter encontrado o vendedor da gasolina, ao que Walter Rosa respondeu: "Esse homem não existe". ${ }^{55}$ Posteriormente, depois de ser conduzido da Casa de Detenção de Niterói para a Delegacia de Ordem Política e Social (Dops) para prestar depoimento, foi anunciado que Walter Rosa, o Bigode, confessara sua participação no incêndio. ${ }^{56}$ 


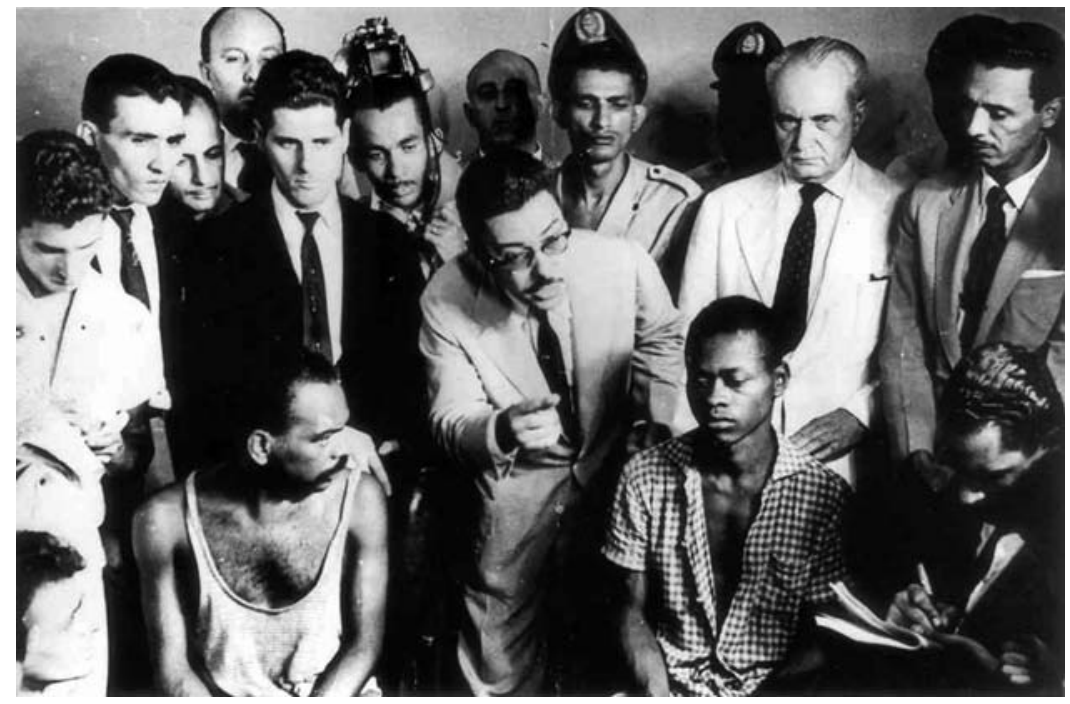

Foto 3 - Interrogatório público dos acusados.

(Dequinha à esquerda, Bigode à direita, ambos sentados, e o governador

Celso Peçanha no centro, em pé.) Fonte: Correio da Manhã. Arquivo Nacional.

Nas páginas dos jornais, por diversas vezes foram anotadas dúvidas sobre o inquérito. O delegado Wilson Friederich foi citado pela imprensa por colocar em dúvida o depoimento. ${ }^{57}$ Noutra nota de jornal, dizia-se que a confissão não havia convencido vários policiais. Chegava-se a comentar que duas correntes haviam se formado na cidade de Niterói. No Correio da Manhã, os críticos seriam apontados como opositores políticos do governador, que o acusavam de responsabilidade. O promotor Paulo Galindo aparecia ainda na imprensa dizendo haver contradições nos depoimentos de Dequinha e da mulher de Walter Rosa. Por fim, a imprensa dizia que o povo estava, igualmente, dividido. ${ }^{58}$

De todo modo, o inquérito dirigido pelo delegado José Alarcão seguiu confirmando a confissão de Adilson Marcelino Alves, o jovem de 21 anos, solteiro, que morava com a mãe no morro da Boa Vista, em Niterói, reconhecido depois, ao sair para comprar sabão para lavar roupa na bica comunitária, tendo sido preso, logo em seguida, na área em que morava. ${ }^{59} \mathrm{O}$ relatório do perito Paulo Pacielo corroborou a hipótese do crime e afastou a hipótese de acidente, mesmo apontando a falta de alternativas de saída e de extintores de incêndio no recinto, de acordo com os jornais da época. Ficava anotado, ainda, 
que a Cia. Brasileira de Energia Elétrica havia considerado precárias as instalações, mas que o quadro de luz manteve a integridade..$^{60}$ Outros depoimentos foram noticiados: o do porteiro conhecido como Pernambuco, confirmando a briga que teve com Dequinha, e de uma senhora que ouvira Dequinha dizendo que iria por fogo no circo. ${ }^{61}$ No decorrer dos depoimentos, José dos Santos, chamado Pardal, também seria arrolado como cúmplice, a partir de declaração do principal acusado. Tal como foi noticiado, mesmo negando, inicialmente, sua participação, Pardal, do mesmo modo que Bigode, terminou admitindo seu envolvimento, assim como de sua mulher, Dirce Siqueira de Assis. ${ }^{62}$

A imprensa definiu, ainda, a imagem pública dos acusados. Na Tribuna da Imprensa apareceu a foto de Adilson Marcelino Alves mostrando o braço, durante a acareação com Walter Rosa, com uma legenda informando que, no dia seguinte ao incêndio, Dequinha teria ido ao Rio de Janeiro para doar sangue para as vítimas do episódio. ${ }^{63}$ Fatos \& Fotos colocava em manchete de página a pergunta sobre o acusado: “louco ou assassino?". A mesma revista acompanhava a cobertura de Manchete ao exibir foto com legenda atestando que o mesmo Dequinha sepultara vítimas da tragédia. ${ }^{64}$

A caracterização do caráter do principal acusado foi marcada ainda pelo pedido de exame de sanidade mental solicitado pela promotoria de Justiça estadual, uma vez que Dequinha já havia sido internado em sanatório anteriormente. Antes de a comissão de peritos ser nomeada, o secretário de Saúde do estado, Dr. Newton Guerra, apareceu nas páginas da imprensa, anunciando tratar-se de "um epilético com baixo nível mental". ${ }^{55}$ Tal como apresenta a sentença, a comissão de especialistas foi composta pelos doutores Luiz Manoel Teixeira Brandão, Renato de Freitas Nogueira da Gama e William Asmar. A perícia médica descreveu Dequinha como "oligofrênico do grau médio" e com base nisso a sentença do juiz passaria a caracterizar o acusado como "imbecil", considerando tratar-se de um caso de ausência de psicose, mas com desenvolvimento mental retardado. ${ }^{66}$

Esse perfil ganhou ainda mais força pelo registro das declarações da mãe do acusado. Ela surgiu nas páginas de Manchete, dizendo: "Meu filho não é um criminoso. Ele é um maluco desde criancinha". ${ }^{67}$ Mas, embora admitindo a loucura do filho, a mãe deixava um problema no ar ao contar que seu filho sempre tivera mania de se culpar. ${ }^{68}$ Nas páginas de O Cruzeiro apareceu o perfil da família de três irmãos, de um casal que nunca oficializou a união e cujo marido havia morrido vários anos antes. Sobre Adilson, o Dequinha, informou-se ter dificuldade de aprendizagem, tendo sido expulso de grupo esco- 
lar, aos 9 anos de idade, e depois fugido do internato que freqüentou, aos 12 anos. Garoto, às vezes ia à casa dos vizinhos para pedir dinheiro. Outras vezes, dormia com porcos e galinhas. O registro do depoimento da mãe dizia só ter visto certa alegria no rosto do filho no dia de sua Primeira Comunhão. Por fim, a mãe admitia que seu filho dava muito trabalho a ela e à polícia, confessando furtos, cujos produtos, porém, não se viam. O perfil marcado pela loucura, porém, pode também ser definido noutro sentido. A revista $O$ Cruzeiro anotou que alguns policiais acreditavam que Dequinha teria aceitado assumir o crime por ser um paranóico exibicionista.$^{69}$ Essa imagem de louco, contudo, continuava a associar loucura e crime. Em sua carta ao leitor, a revista questionou, ainda, se o caso era sobre "o mais desumano dos assassinos ou o mais irresponsável doente mental". ${ }^{70} \mathrm{E}$, assim, o personagem assumia a face de um mistério, tal como concluiu Fatos \& Fotos.

O perfil dos outros envolvidos não foi explorado na mesma medida que o do principal acusado. De todo modo, certas passagens buscaram caracterizá-los como criminosos. O Fluminense realizou entrevista com Walter Rosa, o Bigode, na prisão, definindo-o como "criminoso frio".71 José dos Santos, conhecido como Pardal, por sua vez, cumpria pena na Casa de Detenção e estava naquele domingo em liberdade autorizada. Dirce Maria de Assis e Regina Maria da Conceição, ao serem caracterizadas na qualidade de "amantes", ou "amásias" nas páginas da imprensa, completavam o perfil da vida dos dois cúmplices.

De todo modo, a sentença foi emitida pelo juiz da Primeira Vara Criminal de Niterói, Jovino Machado Jordão, em 23 de outubro de 1962, tendo como base o inquérito desenvolvido. ${ }^{72} \mathrm{~A}$ introdução do documento apresenta como seu trabalho colocava um desafio especial ao juiz: "Não há como não contagiar-se do clima de horror" (p.7). A descrição apresentada diz acompanhar os resultados da investigação indicados pela imprensa da época, com menos detalhes. De todo modo, sua análise o conduziu à seguinte conclusão: "Posso afirmar, pelo que vi, senti, estudei, constatei e concluí que o incêndio do Circo Norte Americano foi criminoso" (p.16). Em certa passagem da sentença tratou o crime como "pacto de celerados" (p.22). Ao final, confirmou que "Adilson Marcelino Alves foi o autor principal dos fatos e que ateou fogo à lona com suas próprias mãos", tendo sido auxiliado por Walter Rosa dos Santos, que "comprou a gasolina atirando-a de encontro à cobertura do circo", e José dos Santos, que ficou "vigiando o local para assegurar sucesso aos autores materiais" (p.30). Resultado: Adilson Marcelino Alves, o Dequinha, foi condenado a 16 anos de prisão com 6 anos de internação em manicômio 
judiciário, por medida de segurança; Walter Rosa dos Santos, o Bigode, foi condenado a 16 anos; José dos Santos, o Pardal, a 14 anos de prisão com temporada prevista em colônia agrícola, também por medida de segurança; as duas mulheres seriam absolvidas pela sentença, por não caracterizarem contribuição efetiva para a prática do delito. Mas a sentença do juiz anota: "Monstros de insensibilidade. Merecerão o nosso desprezo pela falta de qualquer calor humano e de emotividade" (p.34).

Observa-se, assim, que o discurso da imprensa acompanhou o discurso da ação oficial sobre as causas do incêndio do circo de Niterói. Aliás, o próprio poder público passou a usar a imprensa para promover a espetacularização da investigação, como no exemplo do interrogatório público promovido pelo governador. E os jornais e revistas adotaram a linguagem e a visão policial para tratar o fato, dando rosto ao acontecimento e identificando a imagem dos responsáveis. As imagens do circo foram substituídas pelo retrato de Dequinha e seus cúmplices. O incêndio do circo foi representado como caso de polícia, criminalizando o acontecimento.

\section{IMAGEM DO TEMPO}

A lembrança do incêndio do circo, ocorrido em 1961, sobrevive na cidade de Niterói nos dias de hoje. Passados mais de 40 anos, no cotidiano urbano a notícia do passado resiste. Lenir Ferreira de Queiroz Siqueira, umas das sobreviventes do incêndio mais conhecidas na cidade, conta em entrevista que com freqüência, no ônibus, algumas pessoas ao perceberem suas queimaduras perguntam se ela teria se queimado no circo. Segundo ela, na véspera mesmo de seu depoimento, uma moça lhe perguntou por que tinha aquela marca no corpo, e ela teria respondido: "Ah, teve um circo em Niterói, você não era nascida ainda". A moça, porém, teria respondido: "Ah, mas minha mãe fala”, dando a medida da reprodução da lembrança. A observação de Lenir Ferreira de Queiroz Siqueira segue outra passagem de seu depoimento quando conta que quando, ainda nos anos 60, voltou a sair à rua, todos queriam olhar, parar e falar com ela. Nessa altura, a sobrevivente comenta como seu drama se estendeu: "Quando eu saía na cidade era uma tragédia". ${ }^{73}$ Ainda que o episódio repercutisse nos relacionamentos sociais na cidade, nunca deixava de ser lembrado.

Tal como a imprensa organizou a representação do acontecimento entre a tragédia, a solidariedade e o crime, os depoimentos sobre a experiência do 
incêndio na cidade instauram imagens sob tensão. Não são as mesmas imagens, pois a narrativa se inicia antes do desastre. Mesmo assim, guardam a característica ambígua que tensiona as imagens do passado. Na diversidade de recordações se estabelecem imagens entre a fantasia e o horror. A primeira imagem é associada à chegada do circo na cidade, e a outra é associada ao momento em que as chamas tomaram o lugar do espetáculo circense. Repetindo a imprensa, as lembranças daquela época tendem a acentuar as qualidades extraordinárias do circo da família Stevanovich. Luís Gomes da Silva, outro sobrevivente do desastre, lembra assim a chegada da companhia circense: "Era um acontecimento na cidade. Era um acontecimento tão grande, pois passaram com os bichos na rua ... Você via trenzinho e vinha elefante, macaco era aquele negócio". ${ }^{74}$ Lenir completa: "Foi lindo!".75

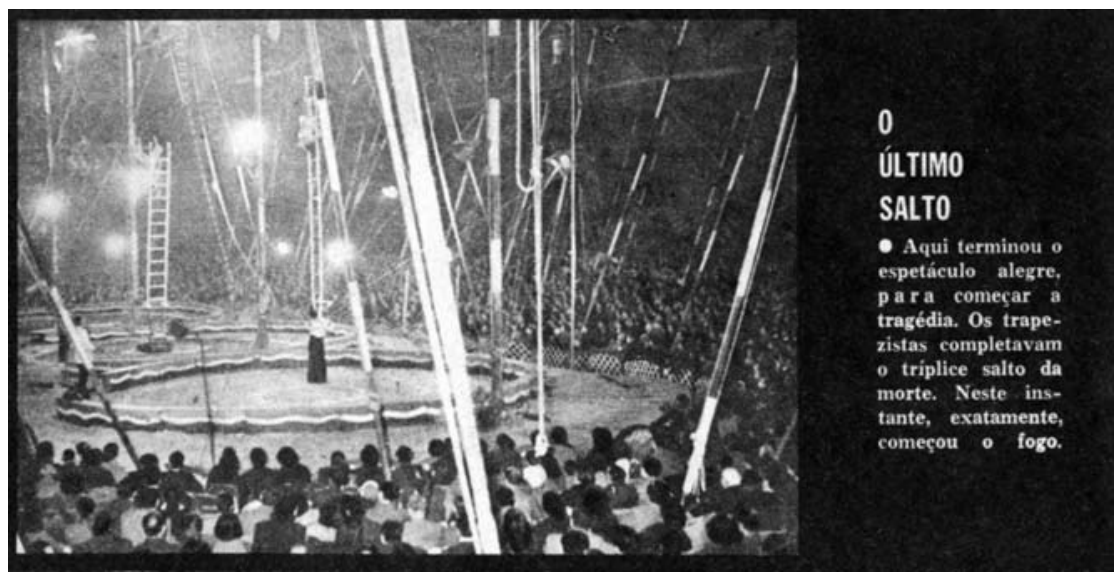

Foto 4 - Espetáculo: o último salto.

Fonte: Fatos \& Fotos. Arquivo LABHOI-UFF.

O palhaço Treme-Treme - que trabalhou no circo Norte-Americano e cujo irmão teria sido o primeiro preso como suspeito, por ser o secretário do circo, o que o obrigou a vir da cidade de Recife, onde se apresentava — descreveu as características do circo, em seu depoimento:

Era dos circos mais ricos que havia na América do Sul ... Foi o primeiro a fazer circo de picadeiro [no Brasil]. O espetáculo deixava o pessoal de boca aberta - uma loucura! - porque era uma revista circense, com grandes atrações da Europa, dos Estados Unidos. Então esse Norte-americano vinha com essa idéia, 
aí tinha artista mexicano, artista alemão, artista francês, artista que ninguém tinha aqui.

Ele fazia o desfile na chegada na cidade ... preparava a praça, preparava tudo, e já botava os cartazes. Mas o cartaz dele? Todo mundo tinha cartaz de $30 \mathrm{~cm}$. O dele tinha 3, 4, 5 metros. Era um absurdo! ... Cartaz todo colorido. Nesse tempo nem se fazia cartaz desse tamanho no Brasil. Eles traziam de Buenos Aires. Anunciando tudo em castelhano. Chegava, fazia passeata, botava banda em cima de uma carreta que ele tinha e entrava na cidade com alto-falante, corneta — "está chegando o Norte-americano!". Para armar a lona em volta do circo ficava assim de gente. A primeira coisa que se fazia era botar a cerca, aí o último caminhão chegava com os animais, iam chegando os animais, aí já estava tudo cercado.

Ah, ele tinham muitas feras ... Tinha três ou quatro elefantes, tinha uns vinte cavalos, tinha dromedário, camelo, hipopótamo ... Nossa! Tinha lhama, bicho que nunca ninguém viu por aqui ... Cavalo deles dava gosto de ver ... Ah, tinha um dos melhores trapezistas do mundo ... Não era banda, era orquestra o que tinha. ${ }^{76}$

A fantasia do esplendor do espetáculo circense se apresenta nos registros da lembrança com a agonia do instante do fogo. Marlene Denise de Oliveira Serrano, que sobreviveu ao incêndio, descreve assim a sua experiência:

Quando gritaram — “fogo!", eu olhei para trás e vi a chama lamber ... Então, não sei te dizer. Meu cunhado e minha cunhada saíram por debaixo das arquibancadas, uma coisa que você não vê. Estourou e todo mundo começou a correr e eu fui junto com as pessoas pelo centro. Foi aquele tumulto: empurra, empurra, empurra. Eu ouvi a minha mãe me gritar, quando olhei para trás já havia uma distância como daqui quase ali na porta e ... pude ver a expressão de terror na fisionomia dela. Depois ... caí num bolo de gente. Eu vi isso quando abri os olhos, porque eu caí de costas, fui empurrada e caí de costas, e a minha vida começou a passar, como se fosse slide. E eu, sufocada, de olhos fechados ... Eu creio que devo ter escorado alguma coisa, algum pano ... porque meu rosto talvez tenha sido um pouco protegido por isso. Ali eu fui sentindo, assim que a vida foi passando, e eu sufocando, sufocando ... Eu falei: “Morri!”. Eu calculei que fosse assim: aquele desespero e, depois, era você se sentir bem. Nisso eu ouvi alguém gritando assim: “Socorro!". Aquelas vozes de pessoas falando, pedindo ajuda, eu abri os olhos e me vi deitada num bolo de gente assim. Eu fiz assim com as mãos e falei: "Ué? - eu não morri não?".

E saí e me vi do lado de fora, com aquilo tudo arriado. E ali, ali foi uma hora tormentosa, porque eu vi quadros muito desagradáveis. Eu vi pessoas completa- 
mente sem pele, descascadas, no chão, pedindo por socorro. Vi bolos de gente ... Eu assisti isso. E fiquei esperando ali, desesperada, aparecer alguém. ${ }^{77}$

As descrições desse instante têm uma força ímpar na palavra de quem vivenciou a experiência. De algum modo, a representação da imprensa registrou o mesmo sentido na sua primeira imagem do acontecimento. Isto se verifica na recorrência de algumas imagens que entre as notícias da imprensa de época e lembrança se repetem, como no caso da referência aos sapatos amontoados no local do desastre. Nélia Siqueira Dupuy, mãe de um menino que sobreviveu aos cinco anos de idade, recorda o que chamou sua atenção no picadeiro incendiado: "Quando nós chegamos lá, eu vi que a coisa tinha sido realmente muito feia, porque o que tinha de sapato...." ${ }^{78}$

Um outro universo de lembrança na cidade se refere à solidariedade. Nelli Gomes, da Associação Fluminense de Reabilitação, rememorou ao afirmar: "Muito, foi muita solidariedade. Todo mundo ia pra lá". ${ }^{79}$ Luís Carlos Pereira Rodrigues lembra como seu pai, carpinteiro, foi ao estádio Caio Martins, colaborar na fabricação de esquifes. ${ }^{80} \mathrm{O}$ médico Carlos Caldas conta como foi levado ao movimento de solidariedade, ao retornar de Petrópolis, do baile de sua formatura em Medicina:

Eu costumo dizer que foi o meu batismo de fogo como médico. Na acepção da palavra ... Quando chegamos na Praça XV para pegar a barca e atravessar o carro - naquele tempo, ponte era um sonho ainda - eu comecei a notar um movimento muito grande na barcaça. Ambulância e carro entrando. Um falatório, muita coisa. Eu aí desci do carro, já dentro da barca, para saber o que estava se passando. Aí me disseram: pegou fogo no circo de Niterói. Eu fiquei desesperado, porque a minha mãe não foi ao baile. Evidentemente, não foi ao baile porque ficou com meu irmão menor, caçula, e eles iriam ao circo. Então, já começou meu drama. Aí, começamos logo a trabalhar. Sofri logo um impacto terrível porque o primeiro paciente que eu fui atender, um minuto ou dois depois ele morreu. Então, aquilo já me traumatizou muito. ${ }^{81}$

Assim, o médico, hoje experiente e conhecido em Niterói, considera que o dia do incêndio foi marcante em sua vida, pois, ao receber a notícia da tragédia se misturam a comemoração de sua formatura, a preocupação com a mãe e o irmão menor, a colaboração no atendimento às vítimas e o início de sua carreira de cirurgião. Ivo Pitangui, outro médico, que se tornou o mais famoso cirurgião plástico do Brasil e chefiou a equipe de cirurgiões do episódio, 
ressaltou em seu depoimento que muita gente ajudou. Menciona, entretanto, um detalhe que a imprensa da época não valorizou, mas que se repete em vários depoimentos: "Chegaram caminhões com folhas de bananeira, as pessoas queriam ajudar". ${ }^{2}$ As folhas serviam para o tratamento de queimaduras. Maria Pérola Sodré, que liderou o grupo de escoteiros e lobinhos na cidade na época, relembra como toda a organização foi doar sangue, depois colaborou voluntariamente nos trabalhos do hospital durante bastante tempo, brincando com as crianças internadas, por exemplo. Na cidade, o trabalho de organização no recolhimento de doações foi grande: "Chegava muito remédio, então tinha que separar os objetivos de cada remédio ... o pessoal recolhendo gelo na rua, recolhendo doações na rua, batia nas casas pedindo lençol, ventilador..... E ela avalia suas lembranças:

Ali nós cumprimos a nossa missão. Porque o lema do lobinho, que é a criança de sete a onze anos, é: "o melhor possível". Tudo o que ele faz, tem que ser o melhor que ele pode ... Não esquece... É um acontecimento que não tem condição de esquecer, não tem condição de esquecer, não tem condição de esquecer... foi muito violento, muito violento. ${ }^{83}$

Nessa passagem, a lembrança da solidariedade traduz a ambigüidade de sentimentos contraditórios que a memória do circo carrega: de um lado o orgulho da missão cumprida, mas, de outro, a violência do episódio. Assim, a memória desperta sucessivamente sentimentos contraditórios, colocando-se entre a beleza do espetáculo circense e o horror da morte, entre os desafios de conviver com seqüelas corporais de queimaduras e a nobreza da medicina em salvar vidas, entre a dor do luto e a dignidade da solidariedade. Há, ainda, a dimensão da saudade dos que foram, que se mistura com a hora do desastre, tal como na lembrança de Lenir Ferreira de Queiroz Siqueira ao falar do marido: "Na hora que aconteceu, o mastro principal caiu, veio caindo, e ele gritou: 'Lenir, meu amor'. Eu lembro que ele deu aquele grito que eu tenho no ouvido até hoje. Aquele 'Lenir', que ele me chamava muito - 'Lenir, meu amor'. Tadinho. Era super carinhoso. Meu amor...”.

Os depoimentos, porém, retratam vivências diferentes. As diversas recordações salientam uma marca especial que precisa ser levada em conta no estudo da história do acontecimento. Há os que estiveram no palco central e sobreviveram ao desastre; há os que foram atraídos para esse palco central em busca de alguém que esteve presente no recinto do circo; há, ainda, os que foram atraídos pela ação coletiva de solidariedade, pelo trabalho da medicina, 
pelo trabalho de reportagem. Há como que vários processos distintos, reunidos em torno do incêndio do circo, que se caracteriza como experiência sincrônica estruturada a partir da memória ${ }^{84}$

No caso do incêndio do circo, as diferentes experiências vivenciadas são articuladas por uma memória que possui um enquadramento demarcado pela ambigüidade de sentimentos contraditórios, que foram e continuam sendo sincronicamente mobilizados. A história do acontecimento traduz a sincronia dos sentimentos que envolvem o acontecimento.

\section{IMAGEM DA MEMÓRIA}

O que caracteriza a memória do circo de Niterói é a dificuldade de lembrar. Essa dificuldade reside, certamente, na ambigüidade dos sentimentos contraditórios que mobiliza. Mas sua dificuldade se afirma ainda mais pela difícil convivência com a explicação do fato.

Ao contrário da imprensa, que acompanhou o discurso oficial baseado no processo policial, a memória do acontecimento que vive na lembrança da cidade não parece participar inteiramente do mesmo movimento. Arídio da Costa Rubim, policial militar reformado, recorda na época ter acompanhado o ato da prisão do principal acusado, conhecido como Dequinha. Mesmo assim, ele diz:

O incêndio, por si só, foi criminoso e ao mesmo tempo não foi, porque quem praticou o incêndio era um elemento de capacidade mental mínima, posso dizer assim meio débil mental e por vingança, por não ter no momento obtido a possibilidade de trabalhar como eventual no circo, com raiva, sem atinar do desastre que ele ia provocar... ele não podia prever que aquele incêndio ia ser em grandes proporções, ele pensava que pegava fogo na lona e acabou, ele esqueceu que tinha pessoas abaixo da lona. ${ }^{85}$

Doracy Campos, o palhaço Treme-treme, é taxativo: "Não foi ninguém. A polícia foi que achou que foi, não foi ninguém. Eu estive lá dez dias, examinei tudo lá, nossa, a fiação dele estava super-terrível, e os fios, trinta, quarenta fios grossos, desencapados. Eles, nesse ponto, eram muito relaxados". ${ }^{86} \mathrm{De}$ modo semelhante, Gilberto da Cunha Lopes, jornalista, que na época era repórter da Tribuna da Imprensa e cobriu o episódio de Niterói, também considera que os acusados foram bodes expiatórios para se dar uma satisfação à opinião pública mobilizada. E conclui: "Esta é uma questão que perdura até 
hoje". ${ }^{87}$ Luís Carlos Pereira Rodrigues testemunhou várias situações que envolvem o episódio. Garoto, morador dos arredores, estava jogando futebol com amigos na hora do incêndio. Correu para o local para ver o desastre e ajudar no resgate. Mais tarde, Luís Carlos, vizinho de Dequinha, assistiu à sua prisão sem resistência. $\mathrm{Na}$ análise de suas lembranças, menciona a impressão da reação do eletricista peruano do circo, e termina colocando em dúvida a explicação oficial do crime: "Eu tenho minhas dúvidas", diz ele. Seu depoimento é interessante, pois entre risos projeta um perfil dos outros condenados: "Ah, os cúmplices do Dequinha? Dirce Fantasma bebia cachaça que não agüentava. Uma mendiga que vivia ali na favela do São João. O tal Walter, vivia com um cachorro. Prenderam a ele e o cachorro". Essa imagem contrasta totalmente com a fornecida pela imprensa da época, que via nos acusados um caráter fortemente marcado para o crime. ${ }^{88}$

Essa dúvida sobre a causa do incêndio paira sobre o valor da lembrança do episódio, passados mais de 40 anos. Carlos Caldas considera que o trabalho dignificante não merecia ser esquecido, assim como a lição de evitar tragédias iguais. Em suas palavras: "E a cidade não poderia também esquecer porque ela foi palco de uma tragédia única no mundo" ${ }^{89} \mathrm{O}$ médico ressalta, assim, a exemplaridade do caso. O policial Luís Carlos Pereira Rodrigues, por sua vez, coloca em questão o papel do Estado no episódio, e argumenta: "Agora eu acho que a lembrança tem que ser como medida de respeito às vítimas e acima de tudo alerta para o poder público". ${ }^{90}$ Contudo, a maioria dos depoimentos considera que o acontecimento deve ser esquecido, como para Gilberto da Cunha Lopes, Doracy Campos, o palhaço Treme-Treme, Nelli Gomes. Claramente é o horror da tragédia que afasta a vontade de lembrar. "Quero falar de coisa alegre, o circo agora voltou a ser alegre, um negócio bonito”, diz o palhaço. ${ }^{91}$

A memória do circo, assim, foge da explicação. Ao insistir na tragédia, a memória afirma uma leitura mítica do passado. $\mathrm{O}$ mito transfere o acontecimento para outro tempo, estabelecendo um tempo anterior que se perde nas origens. Um tempo que não diz mais respeito aos homens de hoje, mas que funciona como advertência sobre a força do destino inevitável. O incêndio se afirma na memória como mito e coloca em dúvida a história.

Essa dúvida conduziu a entrevista de Lenir Ferreira de Queiroz, que acredita como outros que a lembrança não resiste, pois, segundo ela, daqui a quarenta anos ninguém mais falará sobre o episódio. Ao mesmo tempo, porém, ela se pergunta: "Amanhã vão dizer que isto é lenda. E não foi lenda. Foi uma coisa terrível que abalou muito a cidade...".92 
O incêndio se coloca, assim, entre memória e história. Portanto, o acontecimento pode ser caracterizado como um fato histórico sincrônico por reunir várias experiências. Mas é um quadro geral de recordação comum, permitindo que as diversas lembranças se complementem e, ainda, encontrem elementos de semelhança com as representações de época, construindo um circuito de imagens que se remetem mutuamente. Em poucas palavras, o acontecimento se fundamenta na leitura do passado.

\section{RESSONÂNCIA}

Como Pierre Nora destaca, um acontecimento "testemunha menos pelo que traduz do que pelo que revela, menos pelo que é do que pelo que provoca". ${ }^{93}$

Ao procurar investigar a história do acontecimento do incêndio do circo de Niterói, não se pode deixar de admitir que a memória do circo se mantém viva na cidade de Niterói ainda nos dias de hoje. Esse quadro surpreende primeiro pelo fato de a cidade, atualmente, ter mais de 450 mil habitantes, ultrapassando muito a população de 245 mil habitantes em 1960, segundo dados de censos demográficos. ${ }^{94}$ Havia, na época, praticamente a metade da população atual. E muitos se transferiram para Niterói no boom imobiliário ocorrido depois da construção da ponte, aprofundando a integração da cidade na região metropolitana do Rio de Janeiro. Além disso, o quadro demográfico envolve também óbitos, nascimentos e transferência para outras cidades, o que deixa claro que muitos que testemunharam os fatos já não se encontram entre nós, ou deixaram a cidade. Portanto, a lembrança do acontecimento não tem como base uma referência testemunhal direta com o acontecimento. E mesmo assim, a cidade não deixa de lembrar.

Mas cabe notar, ainda, que a mesma cidade que lembra também esquece, pois são muito poucos os que se lembram da data ou do ano do incêndio, e é muito raro encontrar alguém que saiba o local onde ocorreu o acidente. Assim, lembrança e esquecimento convivem na construção permanente da memória do incêndio do circo de Niterói. A cidade vive sem a lembrança de informações históricas, mas com a memória que tem a força do mito como chave de leitura do passado.

Entre memória e história é que o acontecimento é verdadeiramente constituído - entre o discurso afetivo da memória e o discurso crítico da história.

Contudo, em Niterói, a memória do circo perdura na cidade mesmo dian- 
te da ausência de rituais ou de monumentos. No seu texto mais conhecido, Pierre Nora propõe o conceito de "lugares de memória" para caracterizá-los como expressão da sociedade contemporânea que materializa o passado, por não justificar mais seus atos pela ancestralidade como as sociedades tradicionais e por não viver, portanto, no plano da memória. ${ }^{95} \mathrm{O}$ caso do incêndio do circo de Niterói apresenta um caso que contradiz essa consideração geral e relativiza o modelo de validade geral. De um lado, a cidade de Niterói é povoada por estátuas que demarcam a memória do civismo da cidade por meio de lugares de memória. ${ }^{96}$ De outro, a cidade continua vivendo da memória reproduzida por meio de sentimentos compartilhados pela lembrança, que não permitem erguer lugares de memória por medo do circo, do fogo, da morte, da fatalidade. A cidade continua a viver no tempo presente o mito dos ideais e práticas da contemporaneidade. As duas experiências da memória se combinam na cidade, relativizando o modelo de inspiração. Pode-se considerar, então, que a sociedade contemporânea não descarta completamente as práticas tradicionais e, antes, se caracteriza pela multiplicidade de leituras do passado. Assim, práticas e atitudes contemporâneas e tradicionais convivem lado a lado, incluindo a convivência de velhos e novos usos do passado. E mesmo diante da experiência urbana contemporânea, a cidade continua a se definir como sentimento...

\section{NOTAS}

${ }^{1}$ Este trabalho foi desenvolvido no âmbito do Laboratório de História Oral e Imagem LABHOI, do Departamento de História da UFF, integrando a linha de pesquisa que trata das relações entre Memória e Cidade. A pesquisa teve uma larga base de cooperação, o que estende a gratidão a muitas pessoas. Destacam-se as entrevistas concedidas por personalidades da cidade de Niterói, realizadas graças aos alunos que se envolveram em trabalho do curso de graduação que ministrei junto com Ana Maria Mauad, na UFF, em 2001, e do qual resultou a produção de um vídeo com o qual essa pesquisa dialoga. Ângela de Castro Gomes, Hebe Mattos, Ismênia de Lima Martins e Mariza Soares foram interlocutoras permanentes, compartilhando o cotidiano do LABHOI, assim como Marisis de Oliveira e Ana Paula Serrano, que ofereceram apoio técnico imprescindível. Fábio Pires Bento e Douglas Thomaz de Oliveira dividiram o trabalho de levantamento de fontes da imprensa e tratamento técnico de entrevistas, como bolsistas do Pibic/UFF-CNPq. Tive a oportunidade de discutir, ainda, a pesquisa com vários colegas no Congresso da Associação Internacional de História Oral, realizado em 2002, na África do Sul, do qual participei com apoio do CNPq. Roberto Conduru, do Instituto de Arte da Uerj, foi o primeiro incentivador da idéia de estudo. Maria Eliza, colega do Departamento de História da UFMG, a certa altura pro- 
vocou minha reflexão. Uma versão parcial deste texto foi discutida em sessão de pesquisa do IHGRJ, em agosto de 2006, a partir de convite feito por Cybele de Ipanema. No mês seguinte, Icléia Thiesen me convidou, também, para discutir esse trabalho entre colegas da linha de pesquisa de Memória e Espaço, do Programa de Pós-Graduação em Memória Social e Documentação da Unirio. Ao Arquivo Nacional devo a cessão das imagens do arquivo do jornal Correio da Manhã. A todos, meus agradecimentos sinceros.

${ }^{2} \mathrm{Na}$ historiografia do século XX ficou conhecida a cruzada do historiador francês Lucien Febvre contra o que ele chamou de história historizante, de caráter factual, que tinha o Estado como sujeito social principal da história e as fontes oficiais como referência, tal como se evidencia nos seus conhecidos ensaios reunidos no livro Combates pela história.

${ }^{3}$ Originalmente o texto foi publicado, em 1972, na revista Communications, n.18, com o título “L'événement monstre”, e, em 1974, incluída na obra coletiva Faire de l'histoire. A publicação brasileira consta de: NORA, Pierre. O retorno do fato. In: NORA, P.; LE GOFF, J. (Dir.) História: novos problemas. 2.ed. Rio de Janeiro: Francisco Alves, 1979; DUBY, Georges. O domingo do Bouvines, 27 de julho de 1214. Rio de Janeiro: Paz e Terra, 1993. A publicação original desse livro, na França, data de 1973. Mais recentemente a problemática do acontecimento na historiografia francesa ganhou repercussão com a publicação do livro de DEWERPE, Alain. Charonne 8 de février 1962: anthropologie historique d'un massacre d'État. Paris: Gallimard, 2006.

4 “238 mortos até esta manhã”. Tribuna da Imprensa, Rio de Janeiro, 18.12.1961.

5 "Mais de 300 mortos, polícia caça suspeito". Tribuna da Imprensa, 19.12.61; e "Quase 400 pessoas morreram no impressionante incêndio". Manchete, Rio de Janeiro, 30.12.61.

6 "Quase 400 pessoas morreram no impressionante incêndio", Manchete, cit.

7 “Espetáculo não pôde acabar. Só faltava o salto da morte". Tribuna da Imprensa, 18.12.61. Nos autos da sentença judicial, consta que o número de espectadores era superior a 3 mil. Cópia da sentença, assinada pelo juiz da Primeira Vara Criminal de Niterói, Jovino Machado Jordão, em 23.10.62 (cópia gentilmente cedida pelo jornalista Wilson Aquino). Nos arquivos do Tribunal de Justiça do Estado do Rio de Janeiro não foi possível encontrar os autos originais.

8 "Incêndio no circo em Niterói: mais de 250 mortos". Tribuna da Imprensa, 18.12.61.

9 “Depoimentos”. Tribuna da Imprensa, 18.12.61.

10 "Na manhã seguinte, a grande área destruída marcava o local”. O Cruzeiro, Rio de Janeiro, 6.01.62.

11 "Espetáculo não pôde acabar. Só faltava o saldo da morte”, Tribuna da Imprensa, cit.

12 “Governo dá Cr\$ 60 milhões pra socorrer as vítimas do circo". Jornal do Brasil, Rio de Janeiro, 19.12.61, Caderno.principal.

${ }^{13}$ RAMALHO, Eduardo. "O dia da tragédia”. O Cruzeiro, 6.01.62. 
14 “O fogo encerrou o espetáculo”. O Cruzeiro, 6.01.62.

15 "Pais e mães, desesperados, tentavam encontrar, em rostos carbonizados, os traços de seus filhos". Fatos \& Fotos, Brasília, 30.12.61.

16 "Estádio Caio Martins foi transformado na maior e mais triste carpintaria do mundo". Fatos \& Fotos, 30.12.61.

17 "Os lugares onde se encontravam os corpos das vítimas, à espera de identificação, eram círculos dantescos de desespero e pranto”. O Cruzeiro, 6.01.62.

18 “Toda Niterói chorando viu passar seus mortos”. Tribuna da Imprensa, 19.12.61.

19 "O cemitério ficou lotado e a procissão da morte teve de subir o morro à procura de mais covas". Fatos \& Fotos, 30.12.61.

${ }^{20}$ MORAES, Mário de. “Depois da catástrofe”. O Cruzeiro, 6.01.62.

${ }_{21}$ “Tragédias causam casos de loucura”. Tribuna da Imprensa, 18.12.61. Contudo, o caso mais célebre que se difundiu na memória da cidade é que o conhecido personagem urbano da região metropolitana do Rio de Janeiro, Profeta Gentileza, teria perdido sua família no incêndio, para explicar a sua trajetória pessoal inusitada como pregador contemporâneo. Apesar de muito difundida, a história não se confirma. Contudo, sua imagem pessoal ficou ligada ao circo, por ter iniciado suas pregações no local, depois de ter a notícia do ocorrido.

22 "Morte ainda ameaça 102 feridos no incêndio do circo". Jornal do Brasil, 20.12.61.

23 "Prosseguem os socorros às vítimas do incêndio". Correio da Manhã, Rio de Janeiro, 19.12.61; "Papa celebra missa por 317 mortos de Niterói”. Jornal do Brasil, 19.12.61, capa.

${ }_{24}$ "Catástrofe circense do Rio e Janeiro provoca comoção no Brasil”. Correio da Manhã, 19.12.61.

25 “Morreu mais uma vítima do sinistro do circo". Correio da Manhã, 20.12.61.

${ }^{26}$ Ibidem.

27 "Niterói continua recebendo mensagens e medicamentos". Correio da Manhã, 21.12.61.

${ }_{28}$ "Catástrofe circense do Rio de Janeiro provoca comoção no Brasil”, Correio da Manhã, cit.

29 “Consternação no interior pela tragédia de Niterói”. Correio da Manhã, 19.12.61.

30 "Papa celebra missa por 317 mortos de Niterói”. Jornal do Brasil, cit.

${ }^{31}$ A participação médica pode ser conhecida também pela publicação de Direito à beleza, primeiro volume das memórias do dr. Ivo Pitangui, chefe da equipe de cirurgiões da ocasião. Trata-se de capítulo importante, considerando que a tragédia constituiu um grande campo para a investigação da cirurgia plástica, lançando o Brasil em posição de liderança. 32 "Papa celebra missa por 317 mortos de Niterói", Jornal do Brasil, cit. 
33 “Catástrofe circense do Rio e Janeiro provoca comoção no Brasil”. Correio da Manhã, cit.

34 "Mais ajuda do exterior para as vítimas do circo", Correio da Manhã, 20.12.61.

35 "Rio correu para ajudar Niterói”, Tribuna da Imprensa, 18.12.61, p.7, caderno principal.

36 "Morte ainda ameaça 102 feridos no incêndio do circo". Jornal do Brasil, cit.

37 "Niterói continua recebendo mensagens e medicamentos”. Correio da Manhã, cit.

38 "Morreu mais uma vítima do sinistro do circo". Correio da Manhã, cit.

39 "Mais de dez milhões para as vítimas do circo”. O Fluminense, Niterói, 4.01.62.

40 “Governo dá CR\$ 60 milhões pra socorrer as vítimas do circo”. Jornal do Brasil, cit.

${ }_{41}$ "Catástrofe circense do Rio de Janeiro provoca comoção no Brasil". Correio da Manhã, cit.

42 "Incêndio do circo em Niterói: mais de 250 mortos". Tribuna da Imprensa, 18.12.61. O Correio da Manhã deu a mesma notícia noutra forma: "Catástrofe circense do Rio de Janeiro provoca comoção no Brasil”, cit.

43 "Positivada ação criminosa na catástrofe”. Correio da Manhã, 23.12.61.

44 “Circo não tinha condição de segurança para funcionar”. Correio da Manhã, 20.12.61; "Morte ainda ameaça 102 feridos no incêndio do circo". Jornal do Brasil, cit.

45 "Acusado confessa ter ateado fogo ao circo"; "Circo não tinha condição de segurança para funcionar". Correio da Manhã, cit.

46 "Morte ainda ameaça 102 feridos no incêndio do circo", Jornal do Brasil, cit.

47 "Mais de 300 mortos, polícia caça suspeito". Tribuna da Imprensa, cit.

48 “Polícia prende suspeitos”. Tribuna da Imprensa, 19.12.61.

49 “Continua caça ao incendiário: perícia demora”. Tribuna da Imprensa, 20.12.61. Consta da sentença final do caso que nos anos de 1951 e 1952, circos da família Stevanovich foram parcialmente incendiados sem conseqüências danosas.

50 "Circo não tinha condição de segurança para funcionar"; "Polícia de Niterói caça suspeito n.1". Correio da Manhã, 20.12.61; "Morte ainda ameaça 102 feridos no incêndio do circo", Jornal do Brasil, cit.; "Caçada ao criminoso terminou num barraco". Tribuna da Imprensa, 21.12.61.

51 "Incendiário confessa: queria vingar-se". Tribuna da Imprensa, 21.12.61.

52 "Acusado confessa ter ateado fogo ao circo"; "Circo não tinha condição de segurança para funcionar", Correio da Manhã, cit.

53 “Governador interroga incendiário”. Correio da Manhã, 22.12.61.

${ }^{54}$ Essa iniciativa seria citada na sentença do processo, como produto do contexto de gran- 
de publicidade assumido pelo fato, e sugere que o governador quis aparecer na televisão. De resto, anota-se que se tratava de procedimento inadequado, considerando que o governador não tinha competência oficial para interrogar os acusados, e concorreu para o descrédito da confissão. Cf. Cópia de sentença do juiz da Primeira Vara Criminal de Niterói, Jovino Machado Jordão, emitida em 23.10.62, p.11.

55 "Governador interroga incendiário", Correio da Manhã, cit.

${ }_{56}$ "Confessou ter ajudado a incendiar o circo de Niterói”. Correio da Manhã, 31.12.61.

57 "Acusado confessa ter ateado fogo ao circo"; "Circo não tinha condição de segurança para funcionar", Correio da Manhã, cit.

58 "Governador interroga incendiário", Correio da Manhã, cit.

59 "Acusado confessa ter ateado fogo ao circo", Correio da Manhã, cit; "Caçada ao criminoso terminou num barraco", Tribuna da Imprensa, cit.

60 "Delegado: positivada ação criminosa na catástrofe". Correio da Manhã, 23.12.61. No jornal O Fluminense, noticiou-se que a perícia havia concluído que a saída do circo estava quase inteiramente obstruída por grades, apontando que foi o local de maior número de mortes, constando, portanto, a imprevidência da direção do circo. "Perícia acusa proprietários do circo", 4.01.62.

${ }_{61}$ "Delegado: positivada ação criminosa na catástrofe", Correio da Manhã, cit. A certa altura, a hipótese do ato de Dequinha foi colocada em dúvida pela análise do depoimento do comerciante de Maricá, chamado Jorge da Silva, que esperava a sessão seguinte ao lado de fora do circo e teria visto três jovens em situação suspeita fazendo uma fogueira ("Circo: delegado duvida da confissão de Adílson”. Correio da Manhã, 24.12.61). Posteriormente, noticiou-se que Dequinha seria apontado como um dos três jovens ("Dequinha é um dos três que faziam a fogueira". Correio da Manhã, 27.12.61; "Ainda não foi escolhida junta médica para o incendiário”. Correio da Manhã, 29.12.61).

${ }_{22}$ "Pardal negou participação no incêndio". Correio da Manhã, 30.12.61; "Incendiários confirmam depoimentos”. O Fluminense, 4.01.62.

${ }_{63}$ "Acareação destrói álibi”. Tribuna da Imprensa, 22.12.61.

${ }_{64}$ "Mistério no Circo — louco ou assassino?". Fatos \& Fotos, 6.01.62; “O incendiário sepultou as vítimas". Manchete, 6.01.62.

${ }_{65}$ "Pedido de exame de sanidade para Adilson". Tribuna da Imprensa, 23 e 24.12.61.

${ }^{66}$ Cópia de sentença do juiz da Primeira Vara Criminal de Niterói, Jovino Machado Jordão, emitida em 23.10.62, p.27.

${ }^{67}$ "O incendiário sepultou as vítimas. Mas a mãe diz que, sendo um débil mental, ele confessará tudo o que quiserem”. Manchete, cit.

${ }_{68}$ "Mistério no circo - louco ou assassino?". Fatos \& Fotos, cit.; "Mãe de Adilson: 'Meu filho sempre se acusa do que não fez"'. Tribuna da Imprensa, 30 e 31.12.61. 
${ }_{69}$ “Polícia de Niterói acusa incendiários”. O Cruzeiro, 6.01.62.

70 “Conversa com o leitor”. O Cruzeiro, 6.01.62.

71 "Bigode confessou finalmente". O Fluminense, 4.01.62.

${ }^{72}$ Cópia de sentença do juiz da Primeira Vara Criminal de Niterói, Jovino Machado Jordão, emitida em 23.10.62.

${ }^{73}$ Entrevista de Lenir Ferreira de Queiroz. Arquivo de História Oral LABHOI-UFF; Luís Gomes da Silva conta também como reconhecia a tristeza em pessoas quando o encontravam, e conta a história de alguém muito próximo com quem deixou de ter contato. Entrevista de Luís Gomes da Silva. Arquivo de História Oral LABHOI-UFF.

${ }^{74}$ Entrevista Luís Gomes da Silva, Arquivo de História Oral LABHOI-UFF.

75 "A gente ia muito a circo. Muito mesmo. De todos os circos que eu tinha ido era o melhor. Era lindo, que era muito grande, que lá encenavam bonito, transparente. A gente ficava olhando para cima, achando aquilo lindo ... Naquele dia era um circo muito bonito. Foi lindo". Entrevista Lenir Ferreira de Queiroz. Arquivo de História Oral LABHOI-UFF.

${ }^{76}$ Entrevista com Doracy Campos, palhaço Treme-Treme. Arquivo de História Oral LABHOI-UFF.

${ }^{77}$ Entrevista de Marlene Denise de Oliveira Serrano. Arquivo de História Oral LABHOIUFF. Outras descrições: "Quase todo mundo, que ficou na frente, foi mais sacrificado. Quem estava na arquibancada, pulou depressa e saiu correndo. E a gente não, a gente tinha aqueles obstáculos, uma cerquinha, só tinha aquele lugar. Tanto que eu lembro perfeitamente que a hora que eu estava saindo daquela cerquinha, para ir para fora, é que nós caímos. Eu caí, ele caiu, todo mundo começou a cair. Você já viu formigueiro como fica um por cima do outro?”, entrevista Lenir Ferreira de Queiroz Siqueira. Arquivo de História Oral LABHOI-UFF; "Então, quando o trapezista sumiu. Aí, minha noiva bateu no meu ombro, falou: Luís, olha o fogo. Estava a minha distância assim de uns 20 metros. Uns 25 metros. Pela multidão. Eu fui cuspido mesmo. Pum... Fui e voltei. Quando eu voltei o cabo de aço me agarrou. Eu saí, e aí eu lutei com o cabo de aço ... Mas aí eu já estava todo queimado. Eu senti que eu estava pegando fogo ... O que eu fiz? Quando eu vi que estava pegando fogo eu comecei a rolar. Eu estava queimando já. Pra apagar o fogo de mim. Aí passou um caminhão que já tinha outras pessoas e me jogaram em cima do caminhão", entrevista com Luís Gomes da Silva. Arquivo de História Oral LABHOI-UFF.

${ }^{78}$ Entrevista de Nélia Siqueira Dupuy; o palhaço Treme-Treme declarou também: "O que eu via de sapato, de gente, Deus me livre, morta”. Entrevista com Doracy Campos, palhaço Treme-Treme. Arquivo de História Oral LABHOI-UFF.

${ }^{79}$ A citação se refere a uma observação realizada durante entrevista com Lenir Ferreira de Queiroz Siqueira. Nelli Gomes também deu seu depoimento à equipe do LABHOI-UFF, que consta da série do Incêndio do Circo de Niterói. Arquivo de História Oral LABHOIUFF. 
${ }^{80}$ Entrevista com Luis Carlos Pereira Rodrigues. Arquivo de História Oral LABHOI-UFF.

${ }^{81}$ Entrevista com Carlos Caldas. Arquivo de História Oral LABHOI-UFF.

${ }^{82}$ Entrevista com Ivo Helcius Jardim de Campos Pitanguy. Arquivo de História Oral LABHOI-UFF.

${ }^{83}$ Entrevista com Maria Pérola Sodré. Arquivo de História Oral LABHOI-UFF.

${ }^{84}$ Esse argumento foi desenvolvido a partir de conversa com Ana Maria Mauad, a quem agradeço a hipótese inicial.

${ }^{85}$ Entrevista com Arídio da Costa Rubim. Arquivo de História Oral LABHOI-UFF.

${ }^{86}$ Entrevista com Doracy Campos, palhaço Treme-treme. Arquivo de História Oral LABHOI-UFF.

${ }^{87}$ Entrevista com Gilberto da Cunha Lopes. Arquivo de História Oral LABHOI-UFF.

${ }^{88}$ Entrevista com Luis Carlos Pereira Rodrigues. Arquivo de História Oral LABHOI-UFF.

${ }^{89}$ Entrevista com Carlos Caldas. Arquivo de História Oral LABHOI-UFF.

${ }^{90}$ Entrevista com Luis Carlos Pereira Rodrigues. Arquivo de História Oral LABHOI-UFF.

${ }^{91}$ Entrevista com Doracy Campos, palhaço Treme-Treme; "Tragédia a gente deve esquecer, né? ... monumento para uma tragédia seria algo como cultuar um velório”, entrevista com Gilberto da Cunha Lopes; "Acho que é uma tragédia muito grande, nós temos que rezar pelos que foram, pelos que ficaram aqui com problema físico, mental, mas não deve ser lembrado, mas, na minha opinião, não deve ser lembrado", entrevista com Nelli Gomes. Arquivo de História Oral LABHOI-UFF.

${ }^{92}$ Entrevista com Lenir Ferreira de Queiroz Siqueira. Arquivo de História Oral LABHOIUFF.

${ }^{93}$ NORA, Pierre. O retorno do fato. In: LE GOFF, J.; NORA, P. História: novos problemas. 2.ed. Rio de Janeiro: Francisco Alves, 1979. p.188.

${ }^{94}$ Niterói, perfil de uma cidade. Niterói: Prefeitura Municipal/SMCT, 1999.

${ }^{95}$ NORA. Pierre. Entre mémoire et histoire: la problématique des lieux. In: Les lieux de mémoire. Paris: Gallimard, 1984. v.1.

${ }^{96}$ KNAUSS, Paulo (Coord.) Sorriso da cidade: imagens urbanas e história política de Niterói. Niterói: Niterói Livros, 2004. 